\title{
The Computation of Income on Sale of Dividend Stock or Subscription Rights
}

TXYULD an Act of Congress taxing as income the whole of the proceeds derived from the sale of dividend stock or of stockholders' preferential subscription rights be constitutional? If not, then would it be within the power of Congress to prescribe a method of computing the income derived from such sales which would render a greater part of the proceeds taxable as income than does the method of computation now in use?

Before discussing these questions it has seemed advisable to devote some space to a general exposition of the power conferred upon Congress by the Sixteenth Amendment. Readers who are conversant with the subject need give the matter under I scant attention.

The Sixteenth Amendment to the federal Constitution (which became effective in February, 1913) empowers Congress "to lay and collect taxes on incomes, from whatever source derived, without apportionment among the several States, and without regard to any census or enumeration." The amendment was rendered necessary by the decision of the Supreme Court of the United States in Pollock v. Farmers' Loan and Trust Company ${ }^{1}$ holding the income tax provisions of the Wilson Tariff Act of $1894^{2}$ to be unconstitutional because the tax was not apportioned among the states according to population. The Constitution provides: "No Capitation, or other direct, Tax shall be laid, unless in Proportion to the Census or Enumeration herein before directed to be taken." 3 The court held this provision to be applicable to taxes on income derived from property on the ground that a tax on income is the same as a tax on its sourceif a tax on the source would be a direct tax, then a tax on the income is a direct tax.

1 (1895) 158 U. S. 601, 39 L. Ed. 1108, 15 Sup. Ct. Rep. 673.

228 U. S. Stats. at L. 509 .

3 U. S. Const, Art. 1, \& 9, par. 4. 
The sole purpose of the Sixteenth Amendment was-and its sole effect has been-the removal so far as income from property is concerned of this restrictive necessity of apportionment from the general power of taxation conferred upon Congress by paragraph 1, section 8 , of article 1 of the Constitution. ${ }^{4}$ Congress is not empowered by the Sixteenth Amendment to lay any taxes which it might not have laid before its adoption had it provided for apportionment of the tax..$^{5}$ And to the extent that any federal income tax law purports to tax without apportionment any form or kind of property not included within the meaning of the word "income" as used in the Sixteenth Amendment, that law is unconstitutional and void.

The Supreme Court said in a case which arose under the Corporation Excise Tax Act of $1909^{6}$ : " 'Income' may be defined as the gain derived from capital, from labor, or from both combined." Confining our attention to income derived from capital it is clear that everything which comes in is not income. There can be no income without gain. Thus if I sell a horse for $\$ 100$, the fact that I paid $\$ 90$ for it must be taken into account. The gain, and consequently the income, is only $\$ 10$. Many economists would deny that the $\$ 10$ constituted income unless I was in the business of buying and selling horses. Their concept of income is such that it includes only annually recurring gains. ${ }^{8}$

\footnotetext{
4 Brushaber v. Union Pac. R. Co. (1916) 240 U. S. 1, 60 L. Ed. 493, 36 Sup. Ct. Rep. 236.

U. S. Const., Art. $1, \S 8$, reads as follows: "The Congress shall have
} Power: To lay and collect Taxes, Duties, Imposts and Excises, to pay the Debts and provide for the common Defence and general Welfare of the United States; but all Duties, Imposts and Excises shall be uniform throughout the United States."

5 Evans v. Gore (1920) 253 U. S. 245, 64 L. Ed. 887, 40 Sup. Ct. Rep. 550. This case decided that a federal district judge could not be subjected to an income tax, imposed under the Sixteenth Amendment in respect to his salary, by reason of the provisions in U. S. Const., Art. $3, \S 1$, that all federal judges shall receive for their services a compensation "which shall not be diminished during their Continuance in Office."

${ }^{6} 36$ U. S. Stats. at L. 11, ch. 6 . This statute, enacted before the adoption of the Sixteenth Amendment, laid an excise tax on corporations, the amount of the tax being measured by the net income of the corporation. While it was stated by Mr. Justice Pitney in the case which upheld its constitutionality [Stratton's Independence v. Howbert (1913) 231 U. S. 399, $58 \mathrm{~L}$. Ed. 285, 34 Sup. Ct. Rep. 136] that this law was not intended to be and was not in any proper sense an income tax law, the cases decided under it have been utilized by the Supreme Court in interpreting the later income tax laws enacted under the Sixteenth Amendment.

T Stratton's Independence v. Howbert, 231 U. S. 399, 415.

8 In England, where incomes have been taxed ever since Parliament in 
But the Supreme Court has held that even in the case of a single isolated transaction profit derived from the sale of capital is income and is taxable as such. ${ }^{2}$ To the definition above quoted it is therefore perhaps necessary to add, as the Supreme Court did add in Eisner v. Macomber, ${ }^{10}$ the proviso: "provided it be understood to include profit gained through a sale or conversion of capital assets."11

A capital gain is not, however, in itself income. Although there cannot be income from capital without gain, there may be gain without income. Even before I sell my horse, which cost me $\$ 90$, it is worth $\$ 100$ to me if it will undoubtedly sell for that price in the market. But this accrued gain does not become income and taxable as such until I do sell the horse and receive the $\$ 10$. In Eisner v. Macomber, Mr. Justice Pitney said, with reference to the above quoted definition:

“... not a gain accruing to capital; not a growth or increment of value in the investment; but a gain, a profit, something of exchangeable value proceeding from the property, severed from the capital however invested or employed, and coming in, being 'derived,' that is, received or drazen by the recipient (the taxpayer) for his separate use, benefit, and disposal; - that is income derived from property. Nothing else answers the description."12

The example of income from capital heretofore discussed has been one of income resulting from a complete change in the form of the original investment. The horse was sold for $\$ 100$, of which $\$ 90$ represented the original investment in a changed form and of which $\$ 10$ constituted taxable income. But it does not matter that the form of the original investment remains unchanged if the addition has been extracted and realized. Just as interest is income to the money-lender so a cash dividend declared and paid on his capital stock is income to the stock-

1799 enacted the law proposed by the younger Pitt, it is only annually recurring gains which are taxed.

9 Merchants' Loan \& Trust Co. v. Smietanka (1921) 255 U. S. 509, 65 L.

Ed. 751, 41 Sup. Ct. Rep. 386.

${ }_{10}$ (1920) 252 U. S. 189, 207, 64 L. Ed. 521, 40 Sup. Ct. Rep. 189.

${ }^{11}$ This is one of the instances in which the Supreme Court, in deciding an income tax case, relied upon one of its prior decisions under the Corporation Excise Tax Act of 1909 . In Doyle v. Mitchell Bros. Co. (1918) 247 U. S. 179, 62 L. Ed. 1054, 38 Sup. Ct. Rep. 467, profit gained through a conversion of capital assets had been held to be income.

12 252. U. S. 189, 207. Italics the court's. 
holder, ${ }^{18}$ although his original investment remains unchanged in the form of his shares of stock in the corporation.

When a corporation which has accumulated a surplus, instead of distributing it among the stockholders in the form of a cash dividend, transfers the surplus to capital account and issues new shares of stock against it to its old stockholders in proportion to their holdings of the old stock, is the value of the dividend stock taxable as income to its recipient on the theory that it represents accrued gain extracted from his original investment which remains unchanged in the form of his old shares of stock? It is so held in Massachusetts and in Wisconsin under the state income tax laws there in force. ${ }^{14}$ But the Supreme Court of the United States has ruled by a five tc four vote that dividend stock does not constitute income to its recipient because, while it might represent accrued gain on the individual stockholder's original investment, that accrued gain is not sufficiently extracted from the original investment. ${ }^{15}$ In Eisner v. Macomber, which held unconstitutional the provisions of the Income Tax Act of 1916 which purported to render stock dividends taxable, Mr. Justice Pitney said:

"A 'stock dividend' shows that the company's accumulated profits have been capitalized, instead of distributed to the

13 It may be noted that the income tax acts take into consideration the source of the individual's income in fixing the rate which he must pay upon it. The ordinary schedule of rates is not applied either to profit from the sale of capital or to dividends upon stock. As to the former, the rate is not progressive but is $12 \% / 2 \%$ regardless of the size of the taxpayer's income. As to the latter, since the corporation has already paid a tax upon the funds distributed, the stockholder is exempted from the normal tax, and compelled to pay only the surtax. It is to be noticed also that losses sustained through the sale of capital are, to a limited extent, deductible by the individual stockholder from his (otherwise) not taxable income. All these matters are within the discretion of Congress.

${ }_{14}$ Tax Commissioner v. Putnam (1917) 227 Mass. 522, 116 N. E. 904, L. R. A. 1917F 806; State v. Nygaard (1921) 174 Wis. 597, 183 N. W. 884; State v. Cary (1923) 181 Wis. 564, 191 N. W. 546.

${ }_{15}$ Although the Sixteenth Amendment was first put into effect by the Income Tax Act of 1913, it was not until 1920 that the inability of Congress to tax stock dividends as income was judicially determined. The 1913 Act did not specifically tax them but the Treasury Department decided that they were taxable within the general clause taxing "income from whatever source derived," and on Dec. 22, 1915 issued a regulation (Treasury Decision, 2274) holding stock dividends to be the equivalent of cash and to constitute taxable income under the same conditions as cash dividends. In Towne v. Eisner (1918) 245 U. S. 418, 62 L. Ed. 372, 38 Sup. Ct. Rep. 158, the Supreme Court held that this regulation was not justified by the 1913 Act. Congress answered by specifically taxing stock dividends in the 1916 Act (39 U. S. Stats. at L. 756 , ch. 463) and the Department continued to collect taxes on them under that and later acts until in 1920 Eisner v. Macomber (infra, n. 16) was decided. 
stockholders or retained as surplus available for distribution in money or in kind should opportunity offer. Far from being a realization of profits of the stockholder, it tends rather to postpone such realization, in that the fund represented by the new stock has been transferred from surplus to capital, and no longer is available for actual distribution.

"The essential and controlling fact is that the stockholder has received nothing out of the company's assets for his separate use and benefit; on the contrary, every dollar of his original investment, together with whatever accretions and accumulations have resulted from employment of his money and that of other stockholders in the business of the company, still remains the property of the company, and subject to business risks which may result in wiping out the entire investment. Having regard to the very truth of the matter, to substance and not to form, he has received nothing that answers the definition of income within the meaning of the Sixteenth Amendment." 16

It is for the same reason-failure to satisfy the requirement of realization-that stockholders' preferential rights to subscribe to new stock ${ }^{17}$ do not constitute taxable income. The right to subscribe to new stock in a corporation has market value (and could consequently be considered income) only when the stock procurable by the exercise of the right will be worth in the market a sum greater than that which must be paid to the corporation by the one exercising the right in order to secure the stock. And this will be the case only-apart from speculative value due to confidence in the earning power of the corporationwhen the corporation had a surplus at the time it issued the rights to subscribe. It is the existence of this surplus which causes the new stock to be worth more in the market than the owner of the subscription rights need pay the corporation to obtain it. If the price of the new stock to right-holders is par,

16252 U. S. $189,211$.

The stock dividend decision provoked much discussion. See the following: Thomas Reed Powell, The Judicial Debate on the Taxability of Stock Dividends as Income, 5 Bulletin National Tax Association, 247; Id., Stock Dividends, Direct Taxes, and the Sixteenth Amendment, 20 Columbia Law Review, 536; Edward H. Warren, Taxability of Stock Dividends as Income, 33 Harvard Law Review, 885.

${ }_{17}$ When a corporation resolves to increase the amount of its capital by issuing and selling new shares, every stockholder has a right of pre-emption of a fractional part of the new issue, at the price fixed for its issuance, proportionate to his fractional share in the corporation's entire stock. Morawetz, Private Corporations (2d ed.) par. 455; 5 Fletcher Cyc. Corp. \$ 3462. The leading case is Stokes v. Continental Trust Co. (1906) 186 N. Y. 285, 78 N. E. 1090, 12 L.R.A.(N.S.) 969, 9 Ann. Cas. 738. 
the rights represent an interest in the surplus proportionate to the number of shares procurable. If the price of the new stock to right-holders is less than par, the rights represent an interest in the surplus because the corporation has transferred the surplus in whole or in part to capital account. This being so, rights are no more income than is a stock dividend. ${ }^{18}$ The surplus, the existence of which gives the rights value and consequently the possibility of being considered income, remains in the hands of the corporation. The second paragraph quoted above from Eisner v. Macomber is fully applicable to the case of subscription rights.

\section{II}

Neither dividend stock nor preferential subscription rights constitute income within the Sixteenth Amendment then, for the reason that there has been no realization-that "the stockholder has received nothing out of the company's assets for his separate use and benefit." But when the individual stockholder sells his dividend stock or subscription rights the requirement of realization is satisfied. Whatever part of the proceeds of such sale represents accrued gain on his original investment is consequently income within the Sixteenth Amendment and is taxable as such.

None of the income tax laws enacted by Congress since the adoption of the Sixteenth Amendment has directed what method shall be employed in the computation of the income realized upon the sale of dividend stock or subscription rights. The Treasury Department has enjoined the use of a method whereby not the whole but only a part of the proceeds from such sales is deemed to be income in the ordinary case. This method will be discussed in a subsequent part of this paper. ${ }^{19}$ For the present we will confine ourselves to an examination of the question whether an Act of Congress specifically taxing as income the whole of such proceeds would be constitutional.

Dividend stock and subscription rights, when received by the individual stockholder, constitute capital owned by him. His

18 Miles v. Safe Deposit \& Trust Co. (1922) 259 U. S. 247, 66 L. Ed, 923, 42 Sup. Ct. Rep. 483.

10 Infra, p. 28. 
capital interest in the corporation-comprising his original investment with whatever gain has accrued since he made that investment-is now evidenced in part by his original shares of stock and in part by the dividend stock or subscription rights. No part of the accrued gain has been realized-all of it still adheres to the original investment. The accrued gain has become part of the capital interest of the individual stockholder, although he has not yet realized it as income. When the dividend stock or subscription rights are sold the sale is, consequently, a sale of capital. This being so the measure of profit from the sale of capital-selling price less cost-must be employed to determine what part of the proceeds constitute income. Such part-and only such part-of the proceeds constitutes income taxable by Congress under the Sixteenth Amendmint as represents the difference between the price obtained and the cost of what was sold. $^{20}$ An Act of Congress specifically taxing as income the whole of proceeds from the sale of dividend stock or subscription rights would be constitutional, therefore, only if the Supreme Court would accede to what would be in effect a Congressional declaration that in all cases dividend stock or subscription rights cost their possessors nothing. Only in that event could the element of gain be deemed to be sufficiently present.

In cases involving ordinary recurring cash dividends the courts do not consider whether the dividend was really gain to the stockholder. He must pay income tax ${ }^{21}$ upon the cash he receives even though he bought his stock at a time when the corporation had already earned and had in its treasury the funds it later distributed as a dividend, e. g., on the day before the dividend was declared. In Lynch v. Hornby ${ }^{22}$ an extraordinary cash dividend, and in Peabody v. Eisner ${ }^{23}$ a dividend in stock of a company other than the dividend paying corporation were held to be income to the stockholder without inquiry whether the assets distributed by the dividends had been acquired before or after the date when the taxpayer acquired his stock.

20 The taxability, as income, of profit derived from the sale of capital is discussed supra, p. 15 .

${ }_{21}$ Surtax only, see n. 13, supra.

22 (1918) 247 U. S. 339, 62 L. Ed. 1149, 38 Sup. Ct. Rep. 543.

23 (1918) 247 U. S. 347, 63 L. Ed. 1152, 38 Sup. Ct. Rep. 546. United States v. Phellis (1921) 257 U. S. 156, 66 L. Ed. 180, 42 Sup. Ct. Rep. 63, and Rockefeller v. United States (1921) 257 U. S. 176, 66 L. Ed. 186, 42 Sup. Ct. Rep. 68, followed Peabody v. Eisner in this respect. 
If the Supreme Court, in passing upon the constitutionality of a statute taxing as income the whole of the proceeds from the sale of dividend stock or subscription rights, should decline to follow these cases and should inquire when the surplus which gave value to the dividend stock or subscription rights had been acquired by the corporation, it would be made apparent that it can neither be affirmed nor denied that, as a general proposition, the whole of the proceeds are gain to the individual stockholder. Sometimes the whole of the proceeds are gain to him; sometimes part, and part only, are gain to him; and sometimes the result of the transaction is that he suffers an economic loss. For a stock dividend can be declared, and subscription rights will have value when issued, only when the corporation has a theretofore acquired surplus. ${ }^{24}$ In substance when the stockholder sells his dividend stock or subscription rights he sells that which just before their issuance was his interest, or some part of his interest, in the surplus then existing in the corporate treasury. But just before the issuance of the dividend stock or subscription rights he had this interest by virtue of his ownership of his original stock in the company. The amount of the gain which the individual stockholder will realize when he sells his dividend stock or subscription rights will therefore depend upon the extent to which his interest in the corporate surplus existing just before their issuance constituted, as to him, unrealized gain which had accrued to his original investment. If some of that surplus was in existence when he bought his stock it was part and parcel of what he then paid for; consequently when he sells his dividend stock or subscription rights some part of his original investment must be attributed to them as cost, with the result that the whole of the proceeds of the sale may not be deemed to be taxable as income under the Sixteenth Amendment. Only in a case where the corporation accumulated the whole of the surplus after the date on which the stockholder bought his stock is the element of gain sufficiently present to warrant the taxation of the whole of such proceeds as income.

There are four possible situations: (1) The individual stockholder may have bought his shares in the corporation at a time when there was no surplus. In such case the whole of the proceeds from

24 This was explained, in the case of subscription rights, supra, p. 17. 
the sale of his dividend stock or subscription rights does represent the stockholder's economic gain: ${ }^{25}$ (2) The individual stockholder may have bought his shares at a time when there was a surplus in the corporate treasury equal to that in its treasury when the dividend stock or subscription rights were issued. Then no part of the proceeds from the sale of his dividend stock or subscription rights represents an economic gain. ${ }^{28}$ (3) Between this case and that first mentioned lies the case in which there was a surplus in the corporate treasury when the individual stockholder bought his shares in the corporation, but that surplus was not so large as was the surplus which existed at the time when the corporation issued the dividend stock or subscription rights. Here there is an economic gain to the individual stockholder, but an economic gain only to the extent of that proportion of the amount by which the present corporate surplus is larger than was the corporate surplus when he bought his stock, which the stock he owns bears to the total issued stock. ${ }^{27}$ (4) Finally the individual stockholder may have bought his shares at a time when there was a corporate surplus larger than the surplus which existed when dividend stock or subscription rights were issued. Here not only does no part of the proceeds from the sale of the dividend stock or subscription rights represent an economic gain, but the vendor has suffered an economic loss. ${ }^{28}$

25 (In the case of dividend stock, examples can be easily imagined. In this and the following notes examples in the case of subscription rights will be given.)

For example: $A$ buys one share of stock in the $\mathrm{X}$ corporation at par, $\$ 100$. The corporation thereafter accumulates a surplus equal to one-half of its total capital stock. A's share becomes worth $\$ 150$. The corporation votes to its stockholders the right to subscribe for an additional share for every one they own, at $\$ 50$ per share. After the new stock is issued a share of the old and a share of the new stock will cach be worth par, $\$ 100$. Accordingly $A$ can and does find a purchaser for his subscription right at $\$ 50$. $\mathrm{He}$ retains his original share of stock, now worth just what he paid for it $-\$ 100$. Consequently the $\$ 50$ received from the sale of his subscription right represents the amount of A's economic gain.

26 For example: A buys one share of stock (par $\$ 100$ ) for $\$ 150$. Subscription rights, as before, at $\$ 50$ per share. After the new stock is issued a share of the old and a share of the new stock will again each be worth par, $\$ 100$, and $A$ will be able to find a purchaser for his subscription right at $\$ 50$. But the $\$ 50$ so received does not represent an economic gain on $A$ 's original investment, since the original share of stock which he retains is now worth just $\$ 50$ less than what he paid for it.

${ }_{27}$ For example: A buys one share of stock (par $\$ 100$ ) for $\$ 125$. The corporation adds to its surplus and A's share becomes worth $\$ 150$. Subscription rights as before, at $\$ 50$ per share. Again, after the new stock is issued a share of the old and a share of the new will each be worth par, $\$ 100$. A sells his subscription right for $\$ 50$. There is an economic gain of only $\$ 25$, since the old share retained is now worth $\$ 25$ less than what A paid for it.

28 For example: A buys one share of stock (par $\$ 100)$ at $\$ 200$. The 
Although in the dividend cases above referred to ${ }^{29}$ the Supreme Court, in order to determine whether the dividend was really wholly gain to the individual stockholder, did not deem it necessary to inquire whether the assets distributed by the dividends had been acquired before or after the date when the taxpayer acquired his stock, the court has insisted upon the presence of gain to the individual taxpayer in cases involving taxes upon profit from the sale of capital. Thus the Income Tax Act of 1916 provided that "for the purpose of ascertaining the gain derived from a sale or other disposition of property, real, personal, or mixed, acquired before March 1, 1913, the fair market price or value of such property as of March 1, 1913, shall be the basis for determining the amount of such gain derived." 30 In Goodrich v. Edwards ${ }^{31}$ it was held that, notwithstanding this provision, when capital acquired before March 1,1913 is sold for less than its cost to the vendor, although for more than its fair market value on that date, there is no income because no gain. Similarly, notwithstanding the "upset" provision, it was held in Walsh v. Brewster ${ }^{32}$ that upon the sale of property bought before March 1, 1913 only so much of the proceeds of the sale were taxable as income as represented a gain over the original cost, although in this case the property was worth at the upset date less than it had cost the taxpayer. In each of the above cases the Supreme Court held a certain part of the proceeds of the sale to be non-taxable solely because it looked to the time when the taxpayer made his original investment im order to ascertain whether the element of gain required by its definition of "income" as used in the Sixteenth Amendment was present. It is a fair inference from these decisions that when a capital investment is liquidated only so much of the proceeds is taxable as income under the Sixteenth Amendment as represents a surplus over and above the amount originally invested by the taxpayer.

Which of these two lines of cases would the Supreme Court follow in passing upon the constitutionality of an Act of Congress

corporation dissipates part of its surplus and A's share becomes worth only $\$ 150$. Subscription rights as before, at $\$ 50$ per share. Again, after the new stock is issued a share of the old and a share of the new will each be worth par, $\$ 100$. A sells his subscription right for $\$ 50$. Here there is an economic loss of $\$ 50$, for the old share retained is now worth $\$ 100$ less than $A$ paid for it.

28 Supra, p. 19.

30 Act of Sept. 8, 1916, ch. $463, \S 2$ (c), 39 U. S. Stats. at L. 757, 758.

31 (1921) 255 U. S. 527, 65 L. Ed. 758, 41 Sup. Ct. Rep. 390.

32 (1921) 255 U. S. 535, 65 L. Ed. 762, 41 Sup. Ct. Rep. 392. 
specifically taxing as income the whole of the proceeds derived from a sale of dividend stock or subscription rights? Would it follow the dividend cases and accede to the Congressional mandate? This it could do, because, by declining to inquire whether or not the surplus (which enabled the corporation to issue the stock dividend or salable subscription rights) had been acquired, in whole or in part, before the date when the taxpayer purchased the stock with respect to which they were issued, it would not discover that the dividend stock or subscription rights should have attributed to them as cost some part of the individual stockholder's original investment. Or would it follow the profit from sale of capital cases, insist upon making such an inquiry, thereby discover that except in a case where the corporate surplus was all accumulated after the individual stockholder bought his stock, ${ }^{33}$ some part of the taxpayer's original investment should be attributed to the dividend stock or subscription rights as cost, and accordingly hold the statute unconstitutional as an attempt to tax as income (i. e., without apportionment among the states) something which was not income because not gain?

The cases involving profit from the sale of capital present the closer analogy. Dividend stock or subscription rights in the hands of a stockholder are part of his capital investment in the corporation -are capital even though they do represent in part or in whole the accrued but yet unrealized gain upon his original investment. The sale thereof is a partial liquidation of the stockholder's capital interest in the corporation. A further indication that the Supreme Court would insist upon an inquiry as to the date of the stockholder's original investment in order to determine whether part thereof should be attributed as cost to the dividend stock or subscription rights sold is furnished by the case of Lynch $\mathrm{v}$. Turrish. ${ }^{34}$ This case involved the taxability as income under the 1913 Act of an extraordinary cash dividend received by the taxpayer in liquidation of his entire interest in the corporation. The taxpayer had purchased his stock long before the date of the enactment of the Sixteenth Amendment and whatever gain had accrued to his original investment had accrued before that date. Although the 1913 Act contained nothing analogous to the "upset" provision of the $1916 \mathrm{Act}^{35}$ the court held that the enhancement of the value of property during a series of

33 E. g., the case supposed, supra, n. 25.

34 (1918) 247 U. S. 221, 62 L. Ed. 1087, 38 Sup. Ct. Rep. 537.

35 Supra, p. 22. 
years prior to March 1, 1913 does not become income when realized subsequent to that date and that consequently no part of the cash dividend received by the stockholder was taxable. Moreover in Eisner v. Macomber, while the provisions of the 1916 Act taxing stock dividends as income were held unconstitutional on the ground that there had been no realization, the court also said, with reference to the contentions of the government:

"There are two insuperable difficulties with this: In the first place, it would depend upon how long he [the taxpayer] had held the stock whether the stock dividend indicated the extent to which he had been enriched by the operations of the company; unless he had held it throughout such operations the measure would not hold true. Secondly, and more important for present purposes, enrichment through increase in value of capital investment is not income in any proper meaning of the term."38

Finally reference may be made to Miles v. Safe Deposit and Trust Company ${ }^{37}$ where, after the Commissioner of Internal Revenue had ruled that the entire proceeds of a sale of subscription rights constituted taxable income under the Act of $1919,{ }^{88}$ the Supreme Court held, as matter of statutory interpretation, that under that Act only so much of the proceeds were taxable as represented the excess of the selling. price over whatever part of the stockholder's original investment was properly attributable as cost to the subscription rights. ${ }^{39}$ If this decision were constitutional law and not merely statutory interpretation it would be conclusive. But the Act of 1919 did not refer to sales of subscription rights or dividend stock specifically. Consequently the decision is analogous to that of Towne v. Eisner ${ }^{40}$ which held that stock dividends were not taxable as income under the 1913 Act, leaving undecided for two years ${ }^{41}$ the question whether a statute specifically taxing them as income would be constitutional-whether they constituted in- . come under the Sixteenth Amendment.

On the other hand, the state courts which hold dividend

36252 U. S. $189,214-215$.

37 Supra, n. 18.

38 Act. of Feb. 24,1919 , ch. 18,40 U. S. Stats. at L. 1057.

39 The method of computing income employed by the District Court in the Miles case was the method now enjoined by the Treasury Department. See infra, p. 28 et seq.

40 Supra, n. 15.

11 Until the decision in Eisner v. Macomber, supra n. 10. See n. 15, supra. While the court was unanimous in Towne v. Eisner, supra, n. 15, Eisner v. Macomber was decided by a five-to-four vote. 
stock to be income to the stockholder when received ${ }^{42}$ (differing from the Supreme Court as to the presence of sufficient realization) do not attribute to the dividend stock any part of the stockholder's original investment as cost. The four judges dissenting in Eisner v. Macomber clearly were satisfied that sufficient gain was present to render the whole value of the dividend stock taxable as income. And the Treasury Department has ruled that the entire selling price of the right to subscribe to bonds, issued by a corporation to its stockholders, is taxable as income under the 1918 and 1921 Acts. ${ }^{48}$

Moreover in United States v. Phellis, 14 a case similar to Peabody v. Eisner, ${ }^{45}$ involving the taxability as income of a dividend in stock of a corporation other than that declaring the dividend, Mr. Justice Pitney reasoned that the court's refusal to inquire whether or not a dividend received by an individual stockholder was really all gain to him was justified because if the stockholder had bought his stock after the corporation had accumulated the assets distributed by the dividend what he then bought presumably comprised (1) the shares of stock and (2) the prospect of a dividend, and presumably the prospect of an income tax diminished the price he paid. It must be conceded that the same reasoning could be employed to dispense with an inquiry whether the whole of the proceeds from the sale of dividend stock or subscription rights constituted gain to the vendor. For the capital which he sells is, just as is a cash dividend, either part of what he bought when he bought his original stock or the fruit thereof. It may be said that he, too, when he bought his stock, presumably bought (1) the shares of stock and (2) the prospect of the issuance of dividend stock or of subscription rights, and that presumably the prospect of an income tax diminished the price he paid.

But this reasoning should not be applied to the case of a sale of dividend stock or of subscription rights. As in other cases dealing with the sale of capital, only the total proceeds of the sale less the cost of the thing sold should be held to be taxable as income under the Sixteenth Amendment. For Mr. Justice Pitney's argument is unsatisfactory; it does not present

42 Supra, p. 16.

43 Bul. III (1924) 15, p. 8; June 1923 Cum. Bul. p. 54, 56. This question has not yet been passed upon by the courts.

\$s Supra, n. 23.

45 Supra, n. 23. 
the true situation. ${ }^{48}$ The injustice it would work if applied to a case in which the result of the sale of the dividend stock or of the subscription rights was that the individual stockholder suffered an economic loss $^{47}$ is apparent. There is a real justification for the court's refusal to inquire into the existence of gain to the individual stockholder where an ordinary recurrent cash dividend is involved. To require the Treasury Department to examine the facts of each case to determine whether or not an annual cash dividend constituted a distribution of assets which had been accumulated by the issuing corporation before the individual stockholder bought his stock-whether the cash was received by the stockholder in part as a liquidation of part of his capital interest or was received by him wholly in realization of a gain which had accrued to that capital interest-would be to impose upon that department a Herculean task. In cases involving an extraordinary cash dividend ${ }^{48}$ and in those involving a dividend in stock of a company other than that issuing the dividend ${ }^{49}$ the justification is less obvious. These cases are comparatively few and it would seem that fairness to the individual stockholder should outweigh considerations of convenience to the administrative officials charged with the enforcement of the income tax laws. ${ }^{50}$ Where the proceeds from the sale of dividend stock or subscription rights are involved there would be even less justification for a refusal to ascertain to what extent the proceeds are gain to the individual stockholder.

It is submitted, therefore, that an Act of Congress specifically taxing as income the whole of the proceeds from the sale of dividend stock or of stockholders' preferential subscriptior rights would be held by the Supreme Court to be unconstitutional unless limited to the case where the surplus which made possible the issuance of the dividend stock or of salable subscription rights was an accumulation by the corporation after the individual stockholder had bought his stock. Such an act, as applied to all other cases, would be outside the scope of the

${ }^{46}$ See Thomas Reed Powell, Income from Corporate Dividends, 35 Harvard Law Review, 362, 370 ff.

47 See the case supposed, supra, n. 27.

48 E. g., Lynch v. Hornby, supra, n. 22.

49 E. g, Peabody v. Eisner, supra, n. 23; United States v. Phellis, supra, n. 23; Rockefeller v. United States, supra, n. 23.

${ }^{50}$ See Thomas Reed Powell, op. cit., 35 Harvard Law Review, 367 ff. 
power conferred upon Congress by the Sixteenth Amendment because: (1) only realized gain is taxable as income; (2) dividend stock and subscription rights constitute capital in the hands of the stockholder, and their sale is a sale of capital; (3) when capital is sold only the profit derived by the vendor from the sale-the selling price less the cost to him-is taxable income; (4) notwithstanding the refusal by the Supreme Court to inquire whether a dividend is all gain to its recipient or is in part a liquidation of his capital interest, such an inquiry would be made when dividend stock or subscription rights are sold, with the result that it would be apparent that, in cases other than the excepted one, dividend stock or subscription rights do cost the stockholder something.

\section{III}

Is it within the power of Congress to prescribe a method of computing the income realized upon the sale of dividend stock or of stockholders' preferential subscription rights which, while it would not render the whole of the proceeds from such sales taxable as income, would render taxable a greater part of such proceeds than does the method now in use?

It has been seen that when dividend stock or subscription rights are sold only such part of the proceeds as represents the excess of the sale price over the cost of the thing sold can constitutionally be taxed as income. The stockholder pays nothing to the corporation when it issues to him dividend stock or subscription rights, but some part of the individual stockholder's original investment in the corporation must usually be attributed to them as cost. This is so because usually some part at least of the surplus in the corporate treasury, the existence of which made possible the issuance of the dividend stock or subscription rights, had already been acquired by the company at the time when the individual stockholder bought his stock and consequently the dividend stock or subscription rights represent, in part at least, some portion of his original investment.

The question is, therefore, really one of methods of determining attributable cost rather than one of methods of computing income. Is the cost which is attributed to dividend stock or subscription rights under the method now enjoined by the Treasury Department the true cost, or by the use of a different accounting method might a different figure just as truly be said to represent that cost? 
The accounting method enjoined by the Treasury Department with respect to dividend stock results in the attribution to each of the shares, old and new, owned by the stockholder after the issuance of the dividend stock, of an equal part of the original investment. ${ }^{51}$ Each of the stockholder's original shares is regarded as no longer representing any larger portion of his original investment than does each of his dividend shares. As a corollary, whatever accrued but unrealized gain is present when the stock dividend is issued is regarded as divided, in its still unrealized character, between the new evidences of the original investment in like proportions. Thus suppose the stockholder owns one share of stock, par $\$ 100$, having paid par for it on some date after March 1, 1913. The corporation declares and distributes a $100 \%$ stock dividend. The stockholder sells the dividend stock for $\$ 110$. The cost of each share-old and new-must be computed as $\$ 100$ divided by 2 , or $\$ 50$. The selling price of the new share, $\$ 110$, less the cost thus attributed to it, $\$ 50$, gives $\$ 60$ as the taxable income realized by the sale. It is to be noted that by this bookkeeping method the cost attributable to the original share has been reduced from $\$ 100$ to $\$ 50$; if the stockholder sells his original share for $\$ 100$ (what he paid for it) he realizes a taxable income of $\$ 100$ less $\$ 50$ (i. e., $\$ 100$ divided by two) or $\$ 50$.

The Department's method in the case of subscription rights is substantially similar. When the new stock, procurable by exercise of the rights, is issued, a share of the old and a share of the new stock will be of equal value. Consequently, the theory behind the departmental rulings demands an equal sum must be attributed as cost to each. But a right holder must pay the corporation for the new shares a certain subscription price and this fact must be taken into account in determining the cost attributable to the subscription rights. The Treasury Department's own formulation of its method is given in the footnote.52 An example will make it clearer: Sup-

51 The cost of both the old shares and the new shares must be determined as follows: ". . . where the stock issued as a dividend is all of substantially the same character or preference as the stock upon which the stock dividend is paid, the cost of each share (or when acquired prior to March 1, 1913 , the fair market value as of such date) of the old shares of stock divided by the total number of the old and new shares ..." (Art. 1548, Reg. 62, 1922 Ed.)

52 "Where the right issued relates to new stock of substantially the same character or preference as the stock with respect to which the right is issued, the cost of each share of the old stock and the right to subscribe to each share of the new (or, if acquired prior to March 1, 1913, the fair market value as of that date) will be the quotient of the cost (or such fair market value) of the old shares of stock, plus the subscription price of the new shares of 
pose the stockholder bought his original share at par, $\$ 100$. Later the company issues to its stockholders the right to subscribe, at $\$ 90$, for one new share for every old one they own. Our stockholder sells the right in the market for $\$ 15$. In accordance with the Department's method the cost of the old share and the cost of the subscription right must be figured at $\$ 100$ plus $\$ 90$ ( $\$ 190)$ divided by 2 , or $\$ 95$. But the sale price of the right must be figured at the actual sale price, $\$ 15$, plus the subscription price, $\$ 90$, or $\$ 105$. Consequently the taxable income the stockholder would derive from the sale of the right would be $\$ 105$ less $\$ 95$ or $\$ 10$. Again it is to be noted that by this bookkeeping method the cost attributable to the original share has been reduced, this time from $\$ 100$ to $\$ 95$; if the stockholder sells his original share at $\$ 100$, he realizes a taxable income of $\$ 100$ less $\$ 95$, or $\$ 5$.

To return to our question: might not Congress enjoin the use of a different accounting method, one which would yield larger taxes when dividend stock or subscription rights are sold?

Suppose a case where the surplus which made possible the issuance of subscription rights was all acquired after the individual stockholder bought his original stock: A buys one share of stock at par, $\$ 100$. The corporation thereafter accumulates a surplus equivalent to $\$ 100$ for every share of stock it has outstanding and then issues a $100 \%$ stock dividend. A then sells his dividend share for $\$ 100$. His original share, which must have been worth $\$ 200$ in the market just before the issuance of the stock dividend, is now worth but $\$ 100$.

This is the case as to which the constitutional objections hereinbefore urged against the taxation as income of the whole

stock, divided by the sum of the number of the old shares and the number of new shares covered by the right. In computing the gain from the sale of the right in accordance with article 1561 the price for which sold shall be considered the sum of the subscription price of the new shares and the selling price of the right. The above rule for computing the gain from the sale of the right to subscribe to stock is subject to the limitation that the gain so computed shall not exceed the amount for which the right is sold; in any case in which this limitation is applied, the gain or loss from the subsequent sale of the stock with respect to which the right was issued shall be determined as if no right to subscribe had been issued with respect to it. Where the stockholder exercises his right to subscribe to new stock of substantially the same character or preference as the stock with respect to which the right is issued, the cost of the old and the new shares (or, if acquired prior to Marcli 1,1913 , the fair market value as of that date) will be the quotient of the cost of the old shares plus the subscription price of the new shares, divided by the total number of the old and the new shares. ..." (Art. 39, Reg. 62, 1922 Ed., as amended by T. D. 3403 , Oct. 18, 1922.) 
of the proceeds of sales of dividend stock or subscription rights are inapplicable. For here the stockholder by selling his dividend stock has received in cash a sum exactly equal to the gain which had accrued on his original investment, but was as yet unrealized, at the moment before the corporation issued the stock dividend. The original investment is retained by the stockholder, and is worth in the market exactly what he originally paid for it. It would seem that Congress could tax as income the whole price received by the stockholder for his dividend stock on the theory that there has been an extraction of gain in that amount from the original investment-the original investment being left intact in its original form.

And similarly suppose that A bought one share of stock at $\$ 100$ and the corporation, having thereafter accumulated a surplus equivalent to $\$ 50$ for every share of stock it has outstanding, issues to its stockholders the right to subscribe for one additional share for every one they own at $\$ 50$ a share. After the new stock is issued a share of the old and a share of the new will each be worth par, $\$ 100$. Accordingly $A$ can and does find a purchaser for his subscription right at $\$ 50$. He retains his original share of stock, now worth just what he paid for it$\$ 100$. Could not Congress direct that here too the taxable income should be computed on the theory that the original investment has been left intact in its original form and that there has been a complete extraction of the theretofore unrealized gain upon it?

To generalize-there would seem to be no reason why Congress might not enjoin a method of computing the income derived from the sale of dividend stock or subscription rights which treated the dividend stock or subscription rights sold as comprising (a) cost-only such part of the original investment as it is necessary to attribute after having attributed (b) all (or an amount equal to the sale price actually obtained) of the accrued but unrealized gain (or loss) upon that original investment, in order to augment the former to a sum equal to the total proceeds from the sale.

The Department's method of computation has never been sanctioned with respect to dividend stock by the Supreme Court.53 With respect to subscription rights the Supreme Court

53 It has been sanctioned by a lower federal court. Towne v. McElligott (1921) 274 Fed. 960. 
did sustain it in Miles v. Safe Deposit \& Trust Company against the objection of the stockholder. ${ }^{55}$ But that case did not purport to be an interpretation of the Sixteenth Amendment or to negative other methods of computation.

Moreover, in one situation the department regulation nowin the absence of express statutory authority-does depart from the Department's general theory and applies the method above suggested. It would be impossible to hold that a man could realize from the sale of subscription rights an income greater than the whole of the proceeds of such sale. Consequently it is provided in Article 39, Regulations 62,58 that when the bookkeeping method generally enjoined would bring about such a result "the gain so computed shall not exceed the amount for which the right is sold; in any case in which this limitation is applied, the gain or loss from the subsequent sale of the stock with respect to which the right was issued shall be determined as if no right to subscribe had been issued with respect to it."

Suppose that the stockholder bought his original share for $\$ 80$, and sold for $\$ 30$ a right issued to him to subscribe for one new share at $\$ 90$. The cost attributable to the right would be $\$ 80$ plus $\$ 90$ ( $\$ 170$ ) divided by 2 , or $\$ 85$, and the attributable sale price would be $\$ 30$ plus $\$ 90$, or $\$ 120$. This would show a profit of $\$ 35$. But since the total proceeds of the sale of the right were but $\$ 30$, the stockholder would be taxed upon an income of not $\$ 35$ but $\$ 30$ ("limitation" in Article 39, Regulations 62, above quoted): And if later he sold his original share at $\$ 90$, he would be called upon to pay taxes on an income of $\$ 10$ (sale price less original cost) and not upon merely $\$ 5$ (sale price less attributable cost).

It would seem that this fact alone is conclusive evidence that there is nothing in the nature of things which compels the attribution of cost to stock dividends and to subscription rights in accordance with the bookkeeping methods enjoined by the Department. If in one situation the Department is compelled by the nature of things to treat the whole proceeds of the sale of rights as constituting gain extracted from the original investment in

6s Supra, n. 18.

55 But see 259 U. S. 247,251 , where it is stated by the court that, since the taxpayer had not appealed, technically the particular method used by the lower court could not be questioned if it did not result in too low a tax upon the stockholder.

56 Supra, n. 51. 
the stock with respect to which the rights were issued, what possible constitutional objection could be raised against an Act of Congress which directed that in all cases of sales of subscription rights or dividend stock that same method should be applied. The fact that the suggested method of computing gain cr loss is capable of universal application whereas the method enjoined by the Department is not is some indication that the former method is more in accord with the nature of thingswill yield results more nearly approximating the truth-than the latter method.

Our conclusions are, then, that it is within the power of Congress to direct that a method of computing gain different from that now employed by the Department and sanctioned in Miles v. Safe Deposit \& Trust Company ${ }^{57}$ and in Towne v. McElligott ${ }^{58}$ - a method which would render a larger proportion of the proceeds from the sale of dividend stock and subscription rights taxable as income-be employed.

But it is to be noted that in the long run the practical effect of the two methods is about the same. If the stockholder should sell both the dividend stock or rights and the stock with respect to which they were issued, the taxable income would be the same under either method. While the method suggested would render a larger part of the proceeds from the sale of dividend stock or subscription rights taxable as income, it would necessarily render taxable as income a correlatively smaller part of the proceeds from the sale of the stock with respect to which the dividend stock or subscription rights were issued. Consequently the recipient of a stock dividend who desired to realize the value of the dividend stock could elect to retain the dividend stock and to sell an equivalent number of the shares with respect to which the dividend was issued, with the result that the major part of his gain would remain in an unrealized state represented by the retained dividend stock. In the case of subscription rights the stockholder could achieve the same result by himself exercising the rights and at the same time selling a number of old shares corresponding to the number of new shares he thus procured.

Is there any way in which these results could be avoided? Could the government treat whichever stock the stockholder 
retained-whether it be, on the one hand, the dividend stock or the stock procured by the exercise of the rights, or, on the other hand, the stock originally held-as representing the major part of the original investment; if so then whichever stock was first sold could be regarded as embodying the major part of the stockholder's gain and the government would be assured that that stockholder could not, by choosing which stock he would sell, delay the realization of his gain. No reason can be seen why Congress could not enact a statute framed so as to accomplish this result. For our survey of the subject has tended to show that the whole matter is one of bookkeeping-that there is no one method which is so in accord with the nature of things that the Congress would be forced to adopt it rather than another.

Douglas Blount Maggs.

San Francisco, California. 